\title{
Characterization of Streptomyces scabies isolates from potato tubers its pathogenic variations in Rawalpindi District
}

\author{
S. Shazia ${ }^{1^{*}}$, F. Naz ${ }^{1}$, A. Rauf ${ }^{1}$, M. Inam-ul-Haq ${ }^{1}$, S. Bushra ${ }^{2}$ \\ ${ }^{1}$ Department of Plant Pathology \\ ${ }^{2}$ Department of Entomology \\ Pir Mehr Ali Shah Arid Agriculture University, Rawalpindi, Pakistan \\ *E-mail: shahziapathologist@gmail.com
}

\begin{abstract}
Potato (Solanum tuberosum L.) has various biotic constraints in its production due to pest attack. Among these, common scab caused by streptomyces scabies is an important disease in potato which causes economic loss with respect to plant yield and quality of tubers. The present study was conducted to determine the pathogenicity, pathogenic variation, characterization of morphological, physiological and biochemical aspects of Streptomyces associated with potato tubers grown in Rawalpindi district. Severity data and pathogenic variation of disease was studied by using different isolation and characterization techniques.
\end{abstract}

Key words: Pathogenicity, characterization, isolation.

\section{Introduction}

Potato (Solanum tuberosum L.) is annual, herbaceous vegetable crop of family Solanaceae. It is the $4^{\text {th }}$ most important food crop of the world. It originated in mountains of South America centuries ago but now it is grown widely in plains of India, Bangladesh, Pakistan, Central America and Argentina etc. (Ahmad et al., 2011). The estimated annual production of potato around the world is 314 million metric tons per year (FAO, 2009). In Pakistan, potato is cultivated on an area of 149 thousand hectares with the production of 3411.6 thousand tons. Potato contains about $79 \%$ water, $18 \%$ starch, $2 \%$ protein, $1 \%$ vitamins, minerals and trace elements. It is grown in about 140 countries (Haase, 2008). In Pakistan, three crops of potato are produced per year i.e., spring and autumn in plain areas and summer crop in hilly areas. All around the world, farmers have to face production constraints like unavailability of disease free seed, poor soil and plant nutrition and lack of improved crop management practices. The constraint has led to low production especially in developing countries like Pakistan (Abbasi et al., 2012).

Potato crop is susceptible to black scurf, highly susceptible to common scab (Streptomyces scabies), powdery scab (Spongospora subterranea), Verticilliumwilt (Verticillum albo-atrum) and cold and frost (Zanoni, 1991).Most prevailing diseases of potato are bacterial wilt caused by Ralstonia solanacearum (Smith et al., 1962). Common scab is caused by Streptomyces scabies (Thaxter) (Lambert \& Loria, 1989), it is prime bacterial pest of potato in India, Asia and Africa (Hill \& Lazarovits, 2005). It belongs to the family Streptomycetaceae. Common scab adversely affects tap root crops and potato tubers. Soil-borne filamentous bacteria of genus Streptomyces is its causative agent. Streptomycetes are saprophytic microorganisms which infect underground plant tissues of their host. The production of Streptomyces scabies phytotoxins is called as thaxtomins. Among Streptomyces species, thaxtomin A is predominant in nature. S. scabies causes common scab on potato (Solanum tuberosum), beet (Beta vulgaris), carrot (Daucus carota), parsnip (Pastinaca sativa), radish (Raphanus sativus), rutabaga 
(Brassica napobrassica) and turnip (Brassica rapa). Streptomyces are common soil inhabitants and form a complex genus comprising nearly 500 species. It appears as randomly distributed shallow, raised or deep-pitted corky lesions. These lesions vary in size and colour but most probably these lesions are brown in color having a few millimeter diameters (Lerat \& Beaulieu, 2009).

In spite of the importance of Common scab, efficient methods to diagnose the disease are lacking. In Rawalpindi District of Pakistan, potato is a very important crop and can be cultivated throughout the year. However, tuber yield is generally much lower than those in Northern areas of country. This is not only because the environmental conditions but also others limiting factors relating to biotic attacks. These are mainly fungus, bacterial and viral agents. Among various biotic factors Streptomyces scabies have been observed as most prevalent in the potato fields of Rawalpindi District during 2008 and 2009-10 the routine visits. Identification of diseased tubers inconspicuous, since pathogen does not destroy the tubers but their surface blemishes which decrease the market value. No systematic research has so far been conducted to find out the actual picture of disease incidence in the area. So, the present study was investigated to determine incidence, pathogenic variation, morphological, physiological and biochemical characterization and occurrence of Streptomyces scabies in potato growing areas in Rawalpindi.

\section{Materials and Methods}

The study was conducted in the laboratory of Department of Plant Pathology, Pir Mehr Ali Shah Arid Agriculture University, Rawalpindi, Pakistan. The Surveys however, was conducted from Taxilla region of Rawalpindi District (Fig. 1).

\section{Survey for disease incidence}

The survey was conducted at the time of harvesting from each field viz. Taxilla, Hassan Abdal, New City and Qazi Abad located in Taxilla Region. Disease incidence (DI) was calculated from each field by using formula:

$$
\text { DI }=\frac{\text { Number of infected tubers }}{\text { Total No. of tubers }} \times 100
$$

Table 1. Location of four fields in Taxilla region of Rawalpindi district along with potato varieties sown and surveyed for the common scab disease incidence.

\begin{tabular}{llll}
\hline Field No. & Location & Size of the field & Potato Cultivar \\
\hline F1 & Taxilla & 5.43 acre & Bartina, Santé \\
F2 & Hassan Abdal & 2.71 acre & Cardinal, Santé \\
F3 & New City & 2.14 acre & Bartina \\
F4 & Qazi Abad & 11 acre & Bartina, Desiree \\
\hline
\end{tabular}

Isolation and purification of bacterial pathogen

Media nutrient agar (NA) was prepared for isolation of bacterium, For isolation of the bacterial pathogen method by Lambert and Loria (1989), Twenty five isolated colonies of the pathogen five each from Qazi Abad (Road Side) AQAR-1, AQAR-2, AQAR-3, AQAR-4, AQAR-5 from Taxilla, BTB-1, BTB-2, BTB-3,BTB-4, BTB-5 from New City, CNC-1, CNC-2, CNC-3, CNC4, CNC-5 from Qazi Abad (Middle Block side), DQAB-1, DQAB-2, DQAB-3, DQAB-4, DQAB-5 from Hassan Abdal, EHA-1, EHA-2, EHA-3, EHA-4, EHA-5 were tested. 


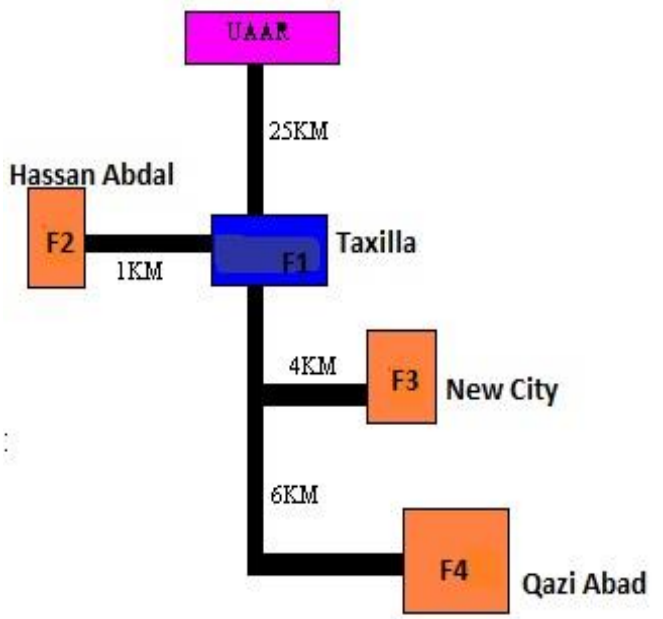

Figure 1. Location of four fields in Taxilla region for the common scab of potato

Hypersensitivity, Preparation of inoculums and Inoculation of Tobacco Plants

The suspension of isolates prepared in sterilized water, was adjusted to contain $3 \times 10^{7} \mathrm{cfu} / \mathrm{ml}$ of colonies of each isolate. Inoculum was injected into the abaxial side of the tobacco leaf with a 1 $\mathrm{ml}$ hypodermic syringe having $0.47 \mathrm{~mm}$ needle. Inoculated plants were covered with plastic bag for $24 \mathrm{~h}$ to maintain high humidity level. After $24 \mathrm{~h}$ the bags were removed and plants were exposed to $28^{\circ} \mathrm{C}$ for almost $36 \mathrm{~h}$ under dark and light conditions (light $14 \mathrm{~h}$ and dark $10 \mathrm{~h}$ ). The control plants were inoculated with sterilized water and were exposed to the same environment. Observations were made after $36 \mathrm{~h}$ of inoculation.

\section{Characterization of pathogen}

A series of physiological tests were performed to characterize the strain as described by Schaad (1998).

Gram staining, potassium hydroxide test, cell shape, size and spore chain morphology, colony colour, growth temperature: All isolates were tested for gram staining following the procedure of Shirling and Gottlieb (1966). The KOH test was only considered positive if stringing occurred within the first $30 \mathrm{~s}$ of mixing the bacteria in the $\mathrm{KOH}$ solution. To observe sporulation, the isolates were inoculated and grown around a round microscope cover slip obliquely inserted in NA plates. The cover slips were removed after sporulation and the adhering mycelium and cell shape, size and spore chains were observed. The effect of various temperatures viz., 18, 28 and $35^{\circ} \mathrm{C}$ on the growth of isolates on NA (nutrient agar) was also studied.

\section{Pathogenicity of selected isolates}

Preparation of inoculum, potting mixture, addition of inoculum and sowing of tubers: Streptomyces scabies isolates resultant mixture was adjusted to $3 \times 10^{7} \mathrm{cfu} / \mathrm{ml}$ by following the method of Bencheikh and Setti (2007). Potting mixture for sowing of potato i.e., sand, clay and farm yard manure (FYM) (1:1:1) was sterilized with $37 \%$ commercial formalin. Certified potato tubers of the cultivar Bartina; known for their sensitivity towards the common scab were inoculated or dipped in bacterial suspension $\left(3 \times 10^{7} \mathrm{cfu} / \mathrm{ml}\right)$ in $50 \mathrm{ml}$ distilled water. Inoculated tubers were immediately covered with soil. 
Common Scab Disease Index: The pathogenic variability among the isolates was documented by employing common scab disease index (CSDI). Scab was examined on all progeny potato tubers for severity and percent area covered by lesions. The severity was assessed on 0-5 visual disease rating scale as described by Bjor and Roer (1980).

$$
\operatorname{CSDI}(\%)=\frac{(\text { Number of tubers in each rating } \times \text { rating })}{\text { Total number of tubers } 5} \times 100
$$

\section{Results and Discussion}

\section{Disease incidence}

It is obvious from the table 2 that the highest incidence of common scab (94\%) was observed in New City field followed by Qazi Abad (84\%), Taxilla (75\%) and the lowest DI i.e., 74\% in Hassan Abdal field.

Table 2. Mean common scab disease incidence in four fields of Rawalpindi district.

\begin{tabular}{llc}
\hline S. No. & Location & Disease incidence (\%) \\
\hline 1 & Taxilla & 75 \\
2 & Hassan Abdal & 74 \\
3 & New City & 94 \\
4 & Qazi Abad & 84 \\
\hline & Mean disease incidence & 81.75 \\
\hline
\end{tabular}

\section{Hypersensitivity}

All test isolates revealed positive hypersensitive response. Hence, to avoid such problem and to confirm the exact nature of the bacterial isolates, they were re-cultured and re-tested but the same results were observed.

\section{Characterization of pathogen}

Streptomyces spp. were isolated from tubers as described by Loria and Davis (1989). Ten isolates viz., AQAR-1, AQAR-2, BTB-1, BTB-2, CNC-1, CNC-2, DQAB1, DQAB-2, EHA-1 and EHA-2 selected for further studies were exposed to different biochemical tests for their characterization.

Table 3. General attributes on biochemical characterization of Streptomyces isolates.

\begin{tabular}{clll}
\hline S.N. & Tests & Observations & Attribute (+/-) \\
\hline 1 & Growth & On NA media & + \\
2 & Hypersensitive & Reaction occur between 24-58 hrs on tobacco plants & + \\
& reaction & & + \\
3 & Pathogenicity & Disease symptoms appears & G+ve \\
4 & Gram staining & Cell counterstained & $60 \mathrm{X}$ magnification \\
5 & Cell size & Average size: & $0.5-2.0 \mu \mathrm{m}$ in diameter) \\
6 & Cell shape & Filamentous, Off white & + \\
7 & Colony color & In general colony were yellow, shiny and smooth & + \\
8 & Growth temp. & Average temperature & $28^{\circ} \mathrm{C}$ \\
\hline
\end{tabular}

Gram staining, potassium hydroxide test, cell shape, size and spore chain morphology, colony colour, growth temperature: Isolates were identified according to the ISP method (Shirling \& Gottlieb, 1966). Morphological, physiological and biochemical characteristics revealed that, all isolates were recorded and confirmed as Gram positive (as their cells were counterstained pinkish). Gram positive bacteria suspended in the $\mathrm{KOH}$ solution generally displayed no reaction 
(absence of stringing). All the test isolates did not show signs of stringing within 30 seconds and even later on repeated strokes. Each isolate when observed under microscope (100X) revealed that cells were filamentous $\sim 1 \mu \mathrm{m}$ wide and the average length of the cells observed were $10-100 \mu \mathrm{m}$. It was observed that the average temperature required for the growth of the bacterium was $28 \pm 2^{\circ} \mathrm{C}$. The results were positively responded this similarity suggests that the isolates obtained from the Rawalpindi region are closely related to Streptomyces scabies.

\section{Pathogenicity}

All the isolates tested on cv. Bartina showed positive pathogenicity response as typical common scab symptoms were observed on the progeny tubers of all treatments as compared with the non inoculated control where no common scab symptoms were observed on progeny tuber. Statistically, there was significant difference between mean common scab disease indexes (CSDI) revealed by the isolates of Streptomyces scabies. Isolate CNC-2 was found most virulent followed by CNC-1, DQAB-1, DQAB-2, BTB-I, BTB-2, AQAR-1, AQAR-2, EHA-2 and EHA-1 (Fig. 2). An isolate was considered to be pathogenic when at least 3 of the 5 tubers developed scab symptoms.

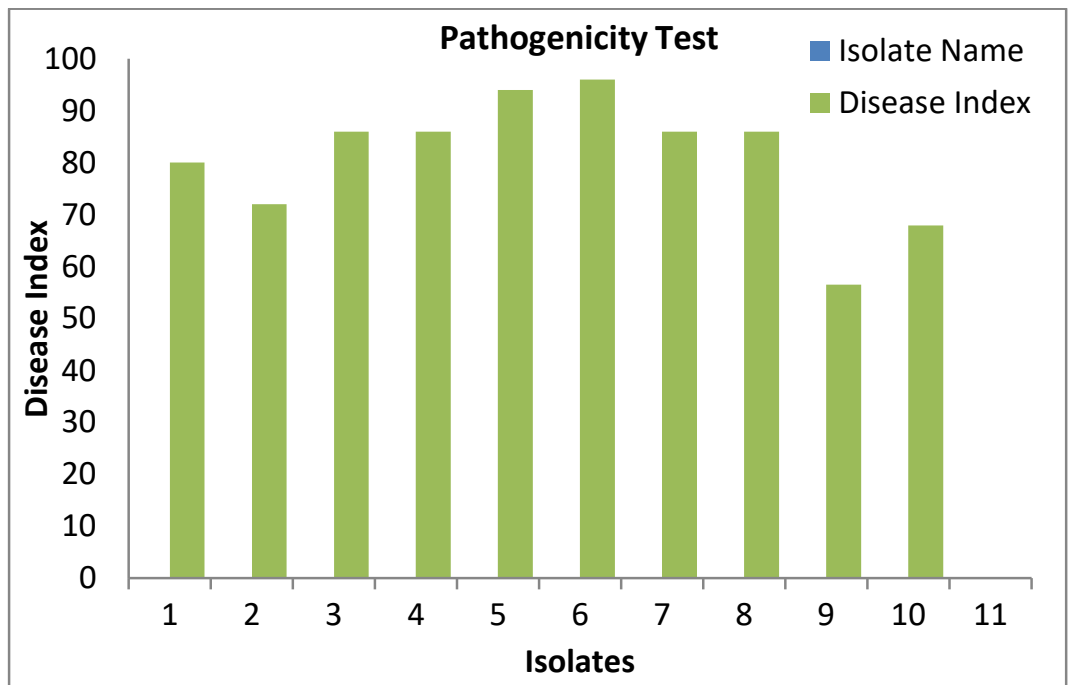

Figure 2. Common scab disease index (\%) shown by 10 isolates of Streptomyces scabies.

Table 4. Common scab disease index of 10 S. scabies isolates on progeny tubers of cv. Bartina.

\begin{tabular}{lccc}
\hline S.No & Name of isolates & Control (Non-inoculated) & Inoculated \\
\hline 1 & AQAR-1 & 0.00 & $80 \mathrm{bcd}$ \\
2 & AQAR-2 & 0.00 & $2 \mathrm{~cd}$ \\
3 & BTB-1 & 0.00 & $6 \mathrm{abc}$ \\
4 & BTB-2 & 0.00 & $6 \mathrm{abc}$ \\
5 & CNC-1 & 0.00 & $4 \mathrm{ab}$ \\
6 & CNC-2 & 0.00 & $6 \mathrm{a}$ \\
7 & DQAB-1 & 0.00 & $6 \mathrm{abc}$ \\
8 & DQAB-2 & 0.00 & $86 \mathrm{abc}$ \\
9 & EHA-1 & 0.00 & $6.540 \mathrm{e}$ \\
10 & EHA-2 & 0.00 & $67.920 \mathrm{de}$ \\
\hline & & LSD $(5 \%)$ & 14.348
\end{tabular}

Means followed by the same letters are significantly different according to LSD test $(\mathrm{P}=0.05)$ 


\section{Acknowledgement}

I am thankful to the Department of Plant Pathology, Pir Mehr Ali Shah Arid Agriculture University, Rawalpindi, Pakistan for facilities.

\section{References}

Abbasi, N.A., M. Zahoor, H.A. Khan \& A.A. Qureshi. 2012. Effect of encapsulated calcium carbide application at different growth stages on potato (Solanum tuberosum L.) growth, yield and tuber quality. Pak. J. Bot. 44(5): 1543-1550.

Ahmad, N., M.A. Khan, N.A. Khan \& R. Binyamin. 2011. Identification of resistance source in potato germplasm against PVX and PVY. Pak. J. Bot. 43(6): 2745-2749.

Bencheikh, M. \& B. Setti. 2007. Characterization of Streptomyces scabies isolated from common scab lesions on potato tubers by morphological, biochemical and pathogenicity tests in chlef region in western Algeria. Sciences \& Technologie $\mathrm{C}^{-\mathrm{N}^{\circ}} 26$. pp. 61-67.

Bjor, T. \& L. Roer. 1980. Testing the resistance of potato varieties to common scab. Potato Research 23: 33-47. http://dx.doi.org/10.1007/BF02364024

FAO, 2009. Economic Survey of Pakistan, 2009-10. Finacae division Economic advisor's wing, Islamabad. pp. 21-22.

Haase, N.U. 2008. The canon of potato science: 50. The nutritional value of potatoes. Potato Res. 50: 415-417. http://dx.doi.org/10.1007/s11540-008-9060-y

Hill, J. \& G. Lazarovits. 2005. A mail survey of growers to estimate potato common scab prevalence and economic loss in Canada. Can J. Plant Pathol. 27: 46-52. http://dx.doi.org/ $10.1080 / 07060660509507192$

Lambert, D.H. \& R. Loria. 1989. Streptomyces scabies spp. nov., nom. rev.International. Journal of Systematic Bacteriology. 39: 387-392. http://dx.doi.org/10.1099/00207713-39-4-387

Lerat S, A.M. \& C. Beaulieu. 2009. Genetic and physiological determinants of Streptomyces scabies pathogenicity. Mol Plant Pathol. 10(5): 579-85. http://dx.doi.org/10.1111/j.13643703.2009.00561.x

Loria, R. \& J.R. Davis. 1989. Streptomyces scabies. In: Laboratory guide for identification of plant pathogenic bacteria. (Schaad, N.W. Ed.), $2^{\text {nd }}$ edition. American Phytopathological Society, St. Paul, MN. pp. 114-119.

Schaad, N.W. 1998. Laborartory guide for identification of plant pathogenic bacteria. American Phytopathol Soc. Press.

Shirling, E.B. \& D. Gottlieb. 1966. Methods for characterization of Streptomyces species. Int. J. Syst. Bacteriol. 16: 313-340. http://dx.doi.org/10.1099/00207713-16-3-313

Smith, L.C., J.M. Ravel, S.R. Lax \& Shivew. 1962. The control of 3-deoxy-arabino-heptulosoniaccid 7-phosphate synthesis by phenylalanine andtyrosine. J. Biol. Chem. 237(3): 566-570.

Zanoni, U. 1991. Potato Atlas and Compendium of Pakistan. PSPDP/PARC, Islamabad, Pakistan. 